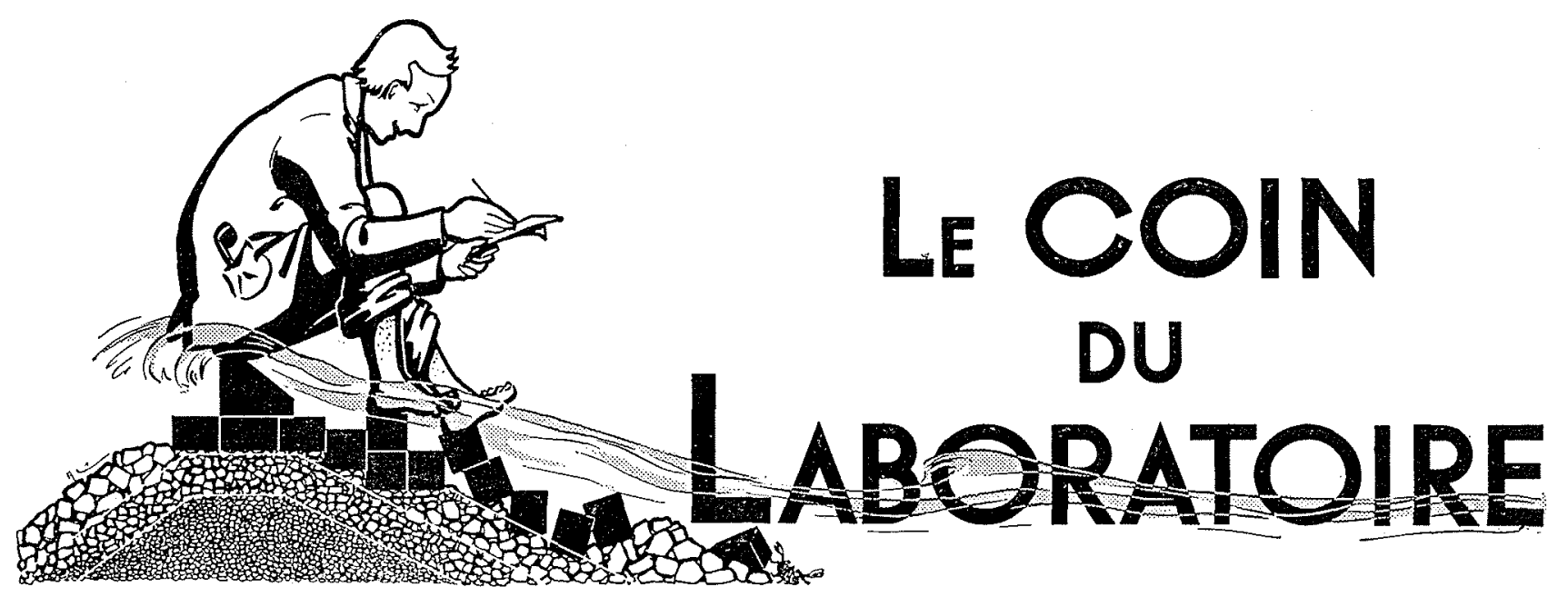

\title{
La mesure de faibles différences de niveau d'un liquide
}

\author{
English text, p. 576
}

PAR P. VAN EEPOEL

PROFESSEUR A L'UNIVERSITÉ LIBRE DE BRUXELLES

\begin{abstract}
Micromanomètre très simple, indéréglable, insensible aux fuites ou évaporation de liquide. Ne nécessitant pas de support particulier, de mise en station, réglage ou autre intervention manuelle. Comportant, dans un ensemble rigide ne donnant lieu at aucun frottement entre solides, son dispositif de mesure, d'étalonnage et de détermination de température pour correction.

Application en aéro et hydrodynamique. Coefficient d'amplification pouvant être très grand $(>2.000)$ associé $\dot{\alpha}$ une portée de mesure, en gamme multiple, pouvant ètre très étendue (plusieurs centimètres).
\end{abstract}

En hydraulique et en aérodynamique il est souvent nécessaire de mesurer de faibles différences de niveau de liquides, généralement, afin de déterminer de petites différences de pression.

Les appareils généralement utilisés à cet effet nécessitent à chaque lecture un réglage ou la vérification et la correction éventuelle de la mise en station. Ces deux opérations sont même souvent nécessaires simultanément. Ces interven- tions manuelles, les fuites et l'évaporation du liquide introduisent des erreurs aléatoires dont l'importance relative peut être grande.

Nous avons, il y a deux ans, présenté un appareil $\left({ }^{*}\right)$ à lecture directe ne comportant aucune intervention manuelle, mise en station, possibi-

(*) Comptes rendus des Séances de l'Académie des Sciences, t. 243, p. 1014 à 1016, séance du 8 octobre 1956. 

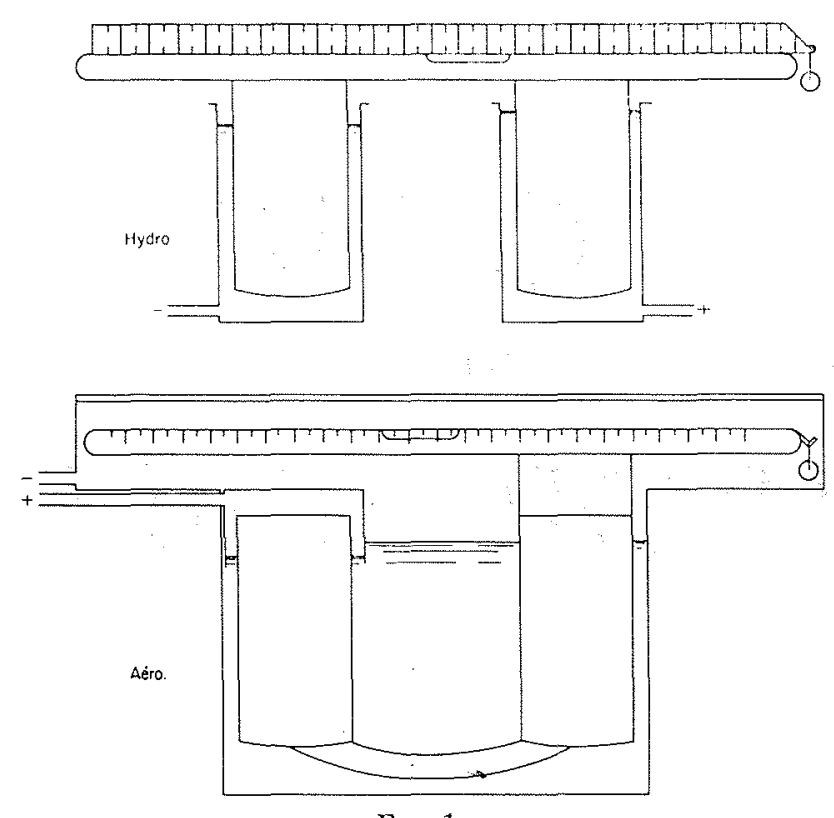

F.IG. 1.

lité de fuite ou d'évaporation et permettant un grandissement supérieur à 1.000 .

L'appareil de mesure est l'ensemble rigide de deux flotteurs. Il flotte sur les liquides dont on désire mesurer la différence des niveaux et s'incline sous l'efYet de la dénivellation.

Il ne comporte aucun frottement entre solides; les résistances qui s'opposent à ses déplacements sont fonction de la vitesse et sans influence sur la précision. Seules les tensions superficielles et les différences de mouillage fixent une limite à celle-ci.

Comme nous le montrerons, l'appareil, bien que très simple, est complet en lui-même. Il renferme son propre dispositif d'élalonnage et une mesure de sa température permettant, s'il $y$ a lieu, d'effectuer la correction de ses indications en fonction de celle-ci.

Si $b$ est la distance entre les axes des flotteurs et $R$ le rayon de courbure de la nivelle, on $a$, entre la mesure $m$, que nous supposons ici être égale à la dénivellation des flotteurs, et la lecture « $l »$, les relations :

$$
\frac{m}{b}=\frac{l}{\mathrm{R}}=\sin \alpha
$$

d'où le grandissement géométrique $G_{\text {, }}$ du dispositif de lecture:

$$
\mathrm{G}_{i f}=\frac{l}{m}=\frac{\mathrm{R}}{b}
$$

Un niveau d'astronomie donnant une « ligne de Paris » par seconde d'angle a un rayon de 466 mètres. La distance entre flotteurs peut être de $0,2 \mathrm{~m}$, d'où $C_{y}=2.330$.

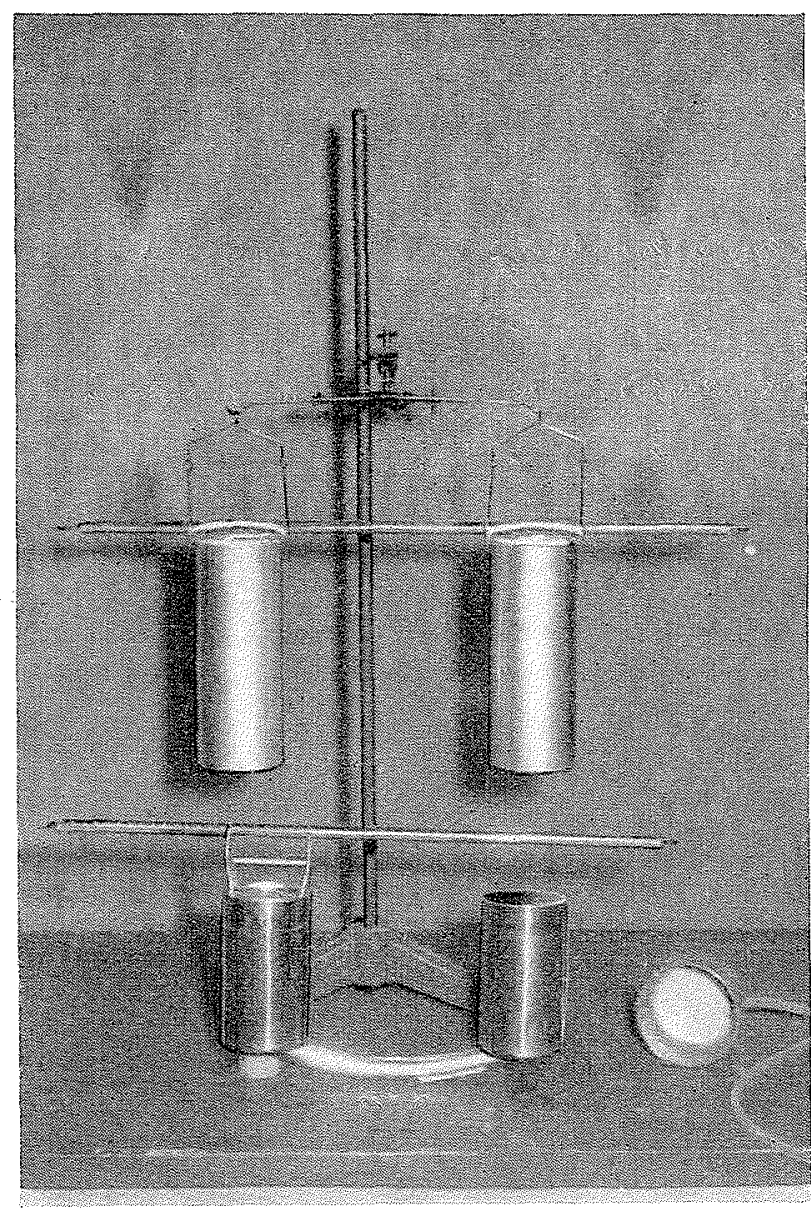

FI(i. 2.

Les nivelles fort sensibles qui, sous une forme peu encombrante, peuvent, dans un dispositif d'amplification, remplacer un levier de longueur égale à leur rayon de courbure, soit 466 mètres dans le cas du niveau ci-dessus, sont peu utilisées en dehors des opérations de nivellement. Citons des contrôles de planéité et certains comparateurs de longueurs. On leur reproche, à juste titre, dans ces applications, la nécessité de disposer d'un support parfaitement fixe et leur sensibilité aux variations de température.

La liaison à la verticale, origine du premier reproche ci-dessus, assure la première vertu essentielle de notre appareil; elle supprime les réglages de la mise en station. Les bassins dans lesquels il flotte peuvent etre deplacés sans que la lecture soit modifiée.

La sensibilité aux variations de température des niveaux résulte généralement d'échauffements locaux ou de l'inégalité des dilatations de la nivelle et de son enveloppe qui donnent lieu a des déformations importantes du tube. Deux niveaux de mécanicien, de même origine et apparemment identiques, peuvent voir leur sensi- 
bilité varier en sens inverse pour une mème variation de la température.

Notre appareil n'a pas à être touché. Il peut ètre complètement enfermé, la lecture se faisant au travers d'une glace. Il est donc facile d'éviter les échauffements locaux. Les variations de la température de la nivelle modifient les conditions d'équilibre. Il en est aisément tenu compte, comme nous le verrons plus loin. La suspension de la nivelle est isostatique, ce qui assure la reproductibilité de ses déformations.

Il n'est pas nécessaire que la courbure de la nivelle soit constante. Il suffit de relever expérimentalement la courbe d'étalonnage:

$$
\mathrm{H}=f(l)
$$

La répartition des poids et la forme donnée aux flotteurs permettent d'agir sur les modifications d'immersion lors de la mesure.

On pourra ainsi réaliser un grandissement $\mathrm{G}_{t}$ de l'appareil différent de l'unité et pouvant notamment lui être supérieur. Le grandissement de l'ensemble $G_{l}$ est égal au produit $G_{a} \times G_{l f}$.

La nivelle, en nous procurant, sous un encombrement réduit, l'équivalent d'une aiguille de très grande longueur, rend superflu le recours à cet artifice.

Il est cependant difficile d'éviter que les variations d'immersion n'agissent dans un sens ou dans l'autre. Il sera même nécessaire de les mettre à profit lorsque l'usage d'une nivelle ne peut ètre envisagé, dans le cas d'un appareil de petites dimensions ou devant fonctionner à température ćlevée, par exemple.

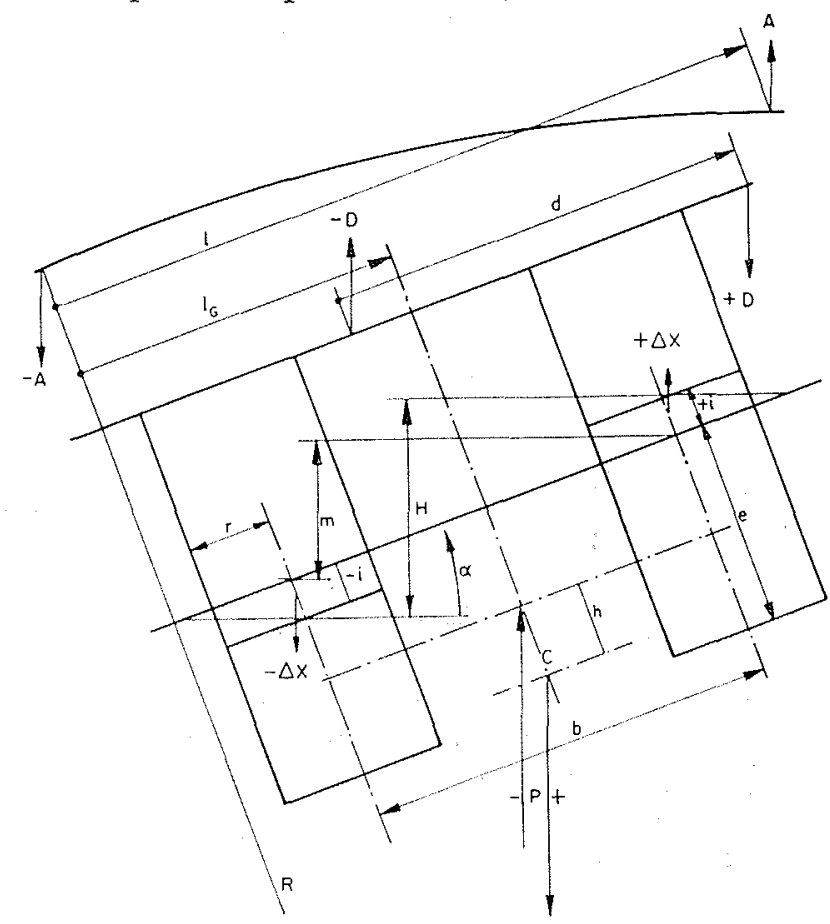

Fici. 3.
Les dispositifs pouvant remplacer les nivelles sont nombreux. On pourra leur conserver les avantages de celles-ci, notamment l'absence de frottements, de réglage, de mise en station, mais ils sont plus compliqués, plus coûteux et leur ćtendue de mesure est plus réduite.

L'appareil représenté figure 2 va nous permeltre de mettre en évidence différents facteurs intéressants.

Les $G$ désignent des grandissements ou amplifications.

Les $k$ sont des inverses de $\mathrm{G} . \quad k=1 / \mathrm{G}$.

$\overline{(1)}=$ poids spécifique du liquide dont on mesure les différences de niveau;

$\mathrm{P}=$ poids de l'appareil complet $\mathrm{y}$ compris nivelle et poids déplaçable $\mathrm{I}$;

$\mathrm{D}=$ poids déplaçable

$\mathrm{A}=$ différence, changée de signe, des poids de la bulle et de son volume de liquide de la nivelle;

$\mathrm{H}=$ différence des niveaux du licpuide;

$l=$ lecture;

$d=$ déplacement du poids déplaçable parallèle à la flottaison initiale;

$\mathrm{R}=$ rayon de courbure de la nivelle.

$\mathrm{E}=\pi r^{2} \cdot \bar{\omega}$.

Les flotteurs sont cylindriques de révolution de rayon $r$.

Nous supposons que lorsque $\mathrm{H}=0, \quad l=0$ et $d=0$, le plan de flottaison est perpendiculaire aux axes des flotteurs.

Une modification de $H, l, d$ amène une inclinaison $\alpha$ de l'appareil.

La valeur maximum de $\alpha$ est fixée par le rayon de coubure et la longueur utile de la graduation de la nivelle.

$\mathrm{R}$ sera supérieur à 25 mètres et $l$ inférieur à 0,5 mètre, d'où $x<0,02$. Nous pourrons remplacer $\sin \alpha$ par $z$ et $\cos \alpha$ par 1 .

Le poids de l'ensemble étant constant, les modifications d'immersion sont égales et de signes contraires.

Les différents couples de forces agissant sur l'appareil constituent ensemble le couple de redressement $\mathrm{C}_{r}$.

On trouve :

$$
\begin{aligned}
& \mathrm{C}_{r}=-\frac{\mathrm{E} b \mathrm{H}}{2} \\
& +\left(\frac{\mathrm{E} b^{2}}{2}+\frac{\mathrm{EH}}{4}+\frac{\mathrm{E} r^{2}}{2}+\mathrm{P} h-\mathrm{AR}\right) \alpha+\mathrm{D} d
\end{aligned}
$$

A l'équilibre, $\mathrm{C}_{r}=0$, ce qui nous donne l'étalonnage:

$$
\mathrm{H}=f(\alpha, d)
$$


L'angle $\alpha$ est transformé en une lecture $l$ par un dispositif quelconque présentant un grandissement $\mathrm{G}_{g}=1 / k_{i}$ aussi élevé que possible.

Si nous utilisons la nivelle à cette fin, nous aurons :

$$
\mathrm{G}_{y}=\mathrm{R} / b
$$

L'élalonnage devient $\mathrm{H}=f(\boldsymbol{l}, d)$, les lectures étant $l$ et $d$.

L'équation d'équilibre devient :

$\mathrm{H}=\frac{b}{\mathrm{R}}\left(1+\frac{r^{2}}{b^{2}}+\frac{\mathrm{H}^{2}}{2 b^{2}}+\frac{2 \mathrm{P} h}{\mathrm{E} b^{2}}-\frac{2 \mathrm{AR}}{\mathrm{E} b^{2}}\right) l+\frac{2 \mathrm{D}}{\mathrm{E} b} d$

Elle est du second degré en $H$. Une des racines est incompatible avec les dimensions de l'appareil. L'autre est la solution de l'équation du premier degré obtenue en négligeant le terme en $\mathrm{H}^{2}$ dans l'équation d'équilibre.

Elle peut s'écrire :

$$
\mathrm{H} \doteq k_{l} l+k_{d} d
$$

en posant :

$\boldsymbol{k}_{l}=\boldsymbol{k}_{\mathrm{g}} \times \boldsymbol{k}_{a}=$ facteur d'influence de l'ensemble;

$k_{a}=1+k_{r}+k_{h}+k_{\mathrm{L}}=$ influence de l'appareil;

$k_{g}=b / \mathrm{R}=$ facteur d'influence du dispositif de lecture;

$k_{r}=r^{2} / b^{2}=$ facteur d'influence de la forme des flotteur's;

$k_{h}=2 \mathrm{P} h / \mathrm{E} b^{2}=$ facteur d'influence des poids fixes;

$k_{\mathrm{I}}=-2 \mathrm{AR} / \mathrm{E} b^{2}=$ facteur d'influence du poids mobile;

$k_{d}=2 \mathrm{D} / \mathrm{E} b=$ facteur d'influence du poids déplaçable.

II sera possible d'élargir considérablement l'étendue de mesure de l'appareil en agissant sur le poids déplaçable. Dans ce cas, le terme en $\mathrm{H}^{2}$ peut ne plus être négligeable. Posons $\mathrm{H}=\mathrm{H}_{0}+\mathrm{H}_{l}$ avec $\mathrm{H}_{0}=k_{d} d$, c'est-à-dire la dénivellation pour $l=0$. Lorsque $\mathrm{H}^{2}$ ne sera plus négligeable, $\mathrm{H}_{l}$ le sera dans $\mathrm{H}^{2}$. Il vient: $\mathrm{H}_{l}=k_{y}\left(k_{u}+k_{\mathrm{H}}\right) l$ avec $k_{\mathrm{II}}=\mathrm{H}^{2} / 2 b^{2}$, d'où il résulte que les courbes d'étalonnage, décalées de $\mathrm{H}_{0}$, ne seront pas tout à fait parallèles. Le plus souvent, cet écart pourra être négligé.

Le placement d'un petit poids additionnel sera considéré comme s'effectuant en deux phases : $1^{\circ}$ introduction du poids sur la verticale du centre de gravité de flottaison, ce qui ne modifie pas la position d'équilibre de l'appareil; $2^{\circ}$ déplacement horizontal du poids assimilable à un poids déplaçable. L'effet du poids additionnel pourra ainsi, aisément, être prédéterminé par le calcul.
Les variations d'immersion $i$, lorsque $d$ est constant, sont données par :

$$
2 i=k_{g}\left(k_{a}-1\right) l,
$$

elles sont nulles lorsque $k_{a}=1$.

Nous n'avons pas tenu compte du poids de l'air ou, de façon plus générale, du gaz ambiant. Son effet peut ne pas être négligeable. Il place la lecture sous la dépendance du poids spécifique du gaz ou de la pression et de la température ambiantes. Cette influence désagréable est évitée en balancant les rolumes émergés, de facon à ce que leur centre de masse se trouve au droit de la résultante des poids.

Ce sera en agissant sur $k_{h}$ que l'on modifiera le plus facilement $k_{a}$; il peut être rendu négatif en changeant le signe de $h$.

Pour que le flotteur soit stable, il faut et il suffit que le module de stabilité $d \mathrm{C} / d \alpha$ soit positif. Un couple de redressement $d \mathrm{C}$ tend à ramener l'appareil à sa position d'équilibre lorsqu'il en est écarté de $d \alpha$.

$$
\frac{d \mathrm{C}}{d \alpha}=k_{a} \frac{\mathrm{E} b^{2}}{2}
$$

A la limite, le grandissement de l'appareil est infini lorsque la stabilité est égale à zéro. La condition de stabilité ne nous empêche donc pas de rechercher de grandes amplifications pour l'appareil. En dédoublant éventuellement un des flotteurs, il sera toujours possible de réaliser la stabilité latérale qui est done sans influence sur le grandissement.

Si nous assimilons l'effet des tensions superficielles et des mouillages à une tension $t$ par unité de longueur de la ligne de flottaison et agissant en sens inverse du mouvement, il se résume à un couple $2 \pi r t b$ introduisant, sur $\mathrm{H}$, une erreur $\pm \varepsilon$ :

$$
\varepsilon=\frac{4 t}{\bar{\omega} r}
$$

qui pourra être réduite en augmentant $r$.

L'équation d'équilibre nous fournit un moyen aisé d'étalonner l'appareil. Il suffit de le faire flotter sur une seule nappe de liquide. On a $\mathrm{H}=0$, d'où :

$$
k_{l}=-\frac{2 \mathrm{D}}{\mathrm{E} b} \frac{d}{l}
$$

D E et $b$ peuvent être mesurés avec toute la précision désirable. La graduation utilisée pour $l$ est également utilisée pour mesurer $d$. Dans le cas d'une nivelle non graduée, ce sera une latte en acier inoxydable portant une graduation et placée sur sa tranche au-dessus du tube. Elle servira de support au cavalier déplacable. Lors- 
que la nivelle est graduée, elle sert de support au cavalier.

La méthode d'étalonnage ci-dessus est difficilement applicable à des flotteurs non cylindriques. Nous utilisons dans ce cas une cuve flottant dans une autre et dont on fait varier l'immersion en la chargeant de poids connus (fig. 3 ).
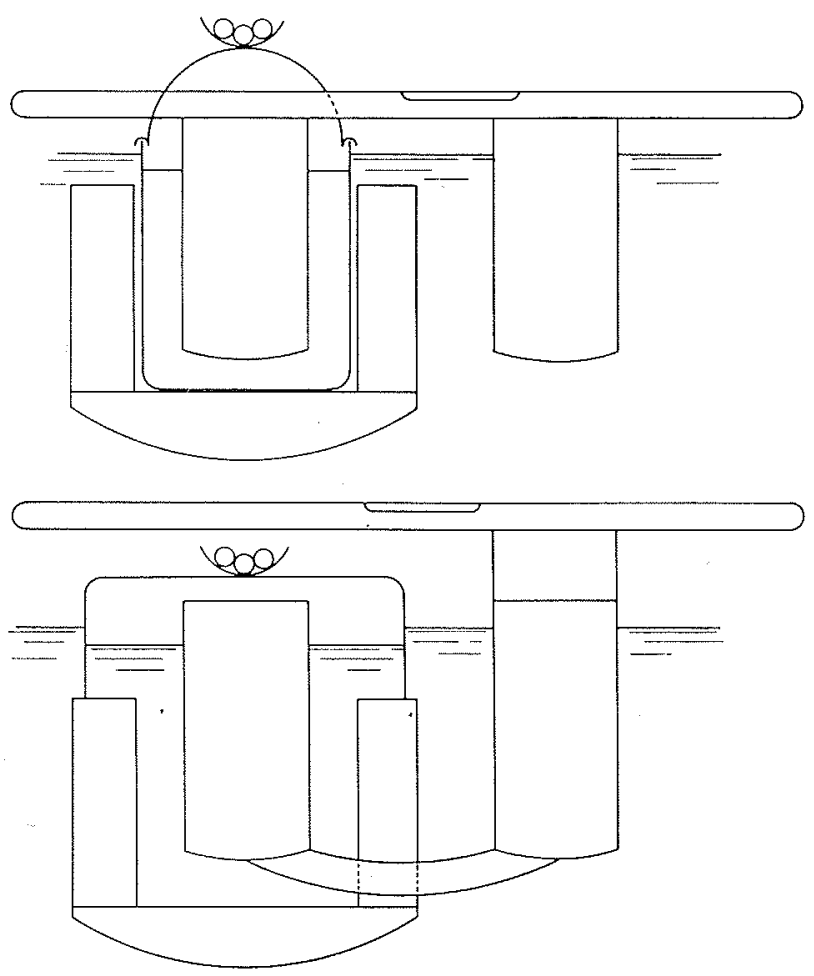

Fig. 4.

Les flotteurs de l'appareil à étalonner sont placés dans ces deux cuves. Il est facile de voir que les erreurs dues aux variations d'immersion de l'appareil et à l'évaporation dépendent de la différence des aires de flottaison intérieure et extérieure de la cuve flottante. Elles peuvent être rendues négligeables.
Par suite de l'inégalité des coefficients de dilatation du liquide et du verre de la nivelle, le volume, la longueur B et le poids A de la bulle, tel qu'il est défini ci-avant, varient.

Le poids total de l'appareil restant constant, la variation $\Delta \mathrm{A}$ est assimilable au déplacement d'un poids $\Delta \mathrm{A}$ du centre de la bulle au centre de masse de la nivelle. Cela donne :

$$
\mathrm{H}=k_{1} l+\frac{2 \Delta \mathrm{A}}{E b}\left(l_{\mathrm{G}}-l\right)=k_{l} l+k_{b}\left(l_{\mathrm{G}}-l\right) \Delta \mathrm{B}
$$

en admettant, pour le calcul de cette correction, que $\Delta A$ est proportionnel ’̀ $\Delta B$.

On détermine facilement $k_{b}$ en relevant, pour $\mathrm{H}=0$, à différentes températures ambiantes et pour différentes valeurs de $\mathrm{D} d$, la lecture $l$ et la longueur $B$ de la bulle.

\section{Applications}

L'appareil, en rendant aisément accessible le domaine des faibles différences de pression ou de niveau, ouvre de larges possibilités, notamment pour les mesures de débits liquides ou gazeux, pratiquement sans accroissement des pertes de charge, c'est-à-dire sans perturber le fonctionnement de l'installation étudiée. Nous l'utilisons ainsi pour la mesure de la quantité d'air aspiré par un moteur à explosion, ainsi que par un foyer fonctionnant en tirage naturel.

Des manipulations d'étudiants, portant sur l'écoulement en conduites de l'air et de l'eau, ont vu leur domaine considérablement élargi par l'emploi de ces micromanomètres.

L'appareil a pu être utilisé sur un chariot automoteur raccordé à un tube de Pitot entraîné par le charriot et immergé dans une nappe d'eau au repos. Il a fourni de bonnes indications montrant son peu d'exigence quant à la fixité des récipients dans lesquels il flotte. 


\title{
LABORATORY PRACTICE
}

\section{Measuring small differences in fluid level}

\author{
BY P. VAN EEPOEL
}

PRORESSOR AT THE "UNIERSTY LIERE", OF BRUSSELS (HELGIUM)

For illustrations, see French text p. 571

\begin{abstract}
1 micromanometer which is simple, cannot get out of order, and is unaffected by the liquid leaking or evaporating. Requires no special bracket, fitting, adjustment or other manual intervention. It consists of a rigid assembly, which does not give rise to friction between solid bodies and which contains devices for measuring, calibration and the determination of temperatures for corrections.

Has applications in aerodynamics and hydrodynamics. Has a potentially large amplification factor $(>2,000)$ associated with a multiple scale measuring range which is potentially very broad (several centimetres).
\end{abstract}

The problem of measuring small differences in fluid level, usually in order to determine minor pressure differences; often occurs in hydraulics and aerodynamies.

The equipment generally used for this purpose either recuires adjusting at each reading, or having its station checked and corrected if necessary, or even both, and the relative magnitude of the random errors caused both by the instruments being handled and by leaks and evaporation of the fluid is sometimes quite considerable.

Two years ago, we presented a direct-reading instrument (*) that does not require any handling nor set up and is completely leak and evaporation proof, and by means of which a magnification factor of more than $1000 \mathrm{X}$ is obtained.

The measuring apparatus consists of a rigid twinfloat assembly, floating on the fluids and tilting under the effect of the level difference.

In this apparatus, there is a total absence of

(*) Comples rendus de l'Acadenie des Sciences, vol. 243 p). 1014-1016, Meeting of the 8 th oct. 1956 . mechanical friction between solid parts, and all the resistances opposing its movements depend upon velocity and do not affect its accuracy, which is solely limited by surface tension and differences in wetting.

As we shall demonstrate, despite its great simplicity, the apparatus is, completely self-contained and has both its own calibration system and a device for measuring its own temperature, so that its readings can be corrected accordingly if necessary.

Taking $b$ as the distance between the float centre lines, and $R$ as the radius of curvature of the level tube, we find the following relationships between the measured value $m$ (which is assumed here to be equal to the difference between the two float levels) and the reading "l":

$$
\frac{m}{b}=\frac{l}{\mathrm{R}}=\sin \alpha
$$

and hence, for the geometrical magnification $G_{g}$ of the reading device: 


$$
\mathrm{G}_{y}=\frac{l}{m}=\frac{\mathrm{R}}{b}
$$

An astronomer's level giving one "Paris line" per angular second has a radius of 466 metres, and the distance between floats can be $0,2 \mathrm{~m}$, so that $\mathrm{G}_{g}=2,330$.

The highly sensitive and very compact level tubes which, in an amplifying device, replaces a lever of the same length as their radius of curvature (i.e. 466 metres for the tube here above mentionned) are very seldom used outside the surveying field. They are employed for such work as tests for straightness and in some length comparators. In these applications, they lave the undeniable disadvantage of requiring on absolutely firm mounting and being highly sensitive to temperature variations.

As it happens, the first of these criticisms, i.e. the instrument's link with the vertical, is one of its essential advantages as far as we are concerned, since it does away with any need for setting-up adjustments, and the tanks in which the floats are placed can be moved without affecting the readings.

The sensitivity to temperature variations of the various types of level gauge is usually due to local temperature rises or uneven expansion of the gauge and its casing, as a result of which the tube undergoes considerable distortion. A given change in temperature can cause quite opposite sensitivity variations in, two apparently identical workshop levels of the same make.

Our instrument has not to be touched; it can be completely enclosed, and the readings taken through a window, thus making it easy to prevent local temperature rises. Although temperature differences in the level tube affect the equilibrium conditions, this is easy to allow for, as we shall see further on. The level tube is isostatically suspended, to ensure that any deformation it undergoes is correctly reproduced.

The curvature of the level tube need not necessarily be constant. An experimental determination of the calibration curve give the relationship :

$$
\mathrm{H}=f(l)
$$

The shapes of the floats and the distribution of the weights are such as to yield changes in immersion during a measurement.

In this way, the instrument magnification $G_{0}$ can be made to differ from unity, and in particular, to exceed it. The overall magnification $G_{l}$ is equal to the product $\mathrm{G}_{a} \times \mathrm{G}_{g}$.

As the level gauge is in itself the equivalent of a very long pointer in a highly compact form, the use of these methods is unnecessary.

However, it is difficult to prevent immersion dilferences from exerting an influence in one direction or the other, and these will even have to be made use in cases where a level gauge cannot be employed, such as with small apparatus or at high temperature conditions.

Although a number of alternative devices can be used instead of level tubes all of which retain the same advantages (viz. in particular, absence of fric- tion: and setting or adjustment requrements) these are all more complicated and expensive besides providing a more limited measuring range.

We shall now bring some interesting features of the instrument shown in Fig. 3 into evidence. The meanings of the various symbols are as follows :

$$
\begin{aligned}
& \mathrm{G}=\text { Magnification or amplification factor; } \\
& k=\text { Reciprocals of } \mathrm{G} \text {, i.e. : } k=1 / \mathrm{G} \text {; } \\
& \varpi=\text { Specific gravity of the liquid in which level } \\
& \text { differentials are to be measured; } \\
& \mathrm{P}=\text { Weight of complete apparatus, including } \\
& \text { level and adjustable weight } \mathrm{D} \text {; } \\
& \mathrm{D}=\text { Aljustable weight; } \\
& A=\text { Difference, with opposite sign, between the }
\end{aligned}
$$

The floats are cylinders of revolution of radius $r$. The plane of flotation is assumed to lie perpendicular to the centre lines of the floats when $\mathrm{H}=0$, $l=0$ and $d=0$.

Changes in $\mathrm{H}, l, d$ cause the instrument to be inclined at an angle $\alpha$.

The maximum value of $\alpha$ is fixed by the radius of curvature of the level tube and the useful length of its graduated scalc.

$\mathrm{R}$ is greater than 25 metres and $l$ is less than 0.5 metre, and hence $\alpha<0.02$. We can replace $\sin \alpha$ by $\alpha$, and $\cos \alpha$ by 1 .

Since the overall weight is constant, the changes in immersion are equal and of opposite sign.

The various couples acting upon the apparatus together form the righting couple $\mathrm{C}_{r}$.

We have :

$$
\begin{aligned}
& \mathrm{C}_{r}=-\frac{\mathrm{E} b \mathrm{H}}{2} \\
& +\left(\frac{\mathrm{E} b^{2}}{2}+\frac{\mathrm{EH}}{4}+\frac{\mathrm{E} r^{2}}{2}+\mathrm{P} h-\mathrm{AR}\right) \alpha+\mathrm{D} d
\end{aligned}
$$

For equilibrium, $\mathrm{C}_{r}=0$, from which we obtain the following calibration relationship :

$$
\mathrm{H}=f(x, d)
$$

The angle $\alpha$ is converted into a reading $l$ by a suitable device providing a magnification $G_{q}=1 / k_{q}$, which should be as high as possible.

By using the level for this pupose, we obtain :

$$
\mathrm{C}_{i}=\mathrm{R} / b
$$


and the calibration becomes $\mathrm{H}=f(l, d)$, the readings being $l$ and $d$.

The equation for equilibrium then becomes:

$$
\mathrm{H}=\frac{b}{\mathrm{R}}\left(1+\frac{l^{2}}{b^{2}}+\frac{\mathrm{H}^{2}}{2 b^{2}}+\frac{2 \mathrm{Ph}}{\mathrm{E} b^{2}}-\begin{array}{c}
2 \mathrm{AR} \\
\mathrm{E} b^{2}
\end{array}\right) l+\frac{2 \mathrm{D}}{\mathrm{E} b} d
$$

The above is an equation of the second degree for $H$. One of its roots cannot be reconciled with the dimensions of the instrument, and the other is the solution of the first-degree equation obtained by neglecting the term $\mathrm{H}^{2}$ in the equation for equilibrium.

It can be written as follows :

$$
\mathrm{H}=k_{l} l+k_{d} d
$$

where :

$k_{l}=k_{g} \times k_{a}=$ a factor allowing for the influence of the whole assembly;

$k_{a}=1+k_{r}+k_{l l}+k_{\mathrm{R}}=$ influence of the apparatus;

$k_{g}=b / \mathrm{R}=$ a factor allowing for the influence of the reading device;

$k_{r}=r^{2} / b^{2}=$ a factor aallowing for the influence of the shape of the floats;

$k_{h}=2 \mathrm{P} h / \mathrm{E} b^{2}=\mathrm{a}$ factor allowing for the influence of the fixed weights;

$k_{\mathrm{I}}=-2 \mathrm{AR} / \mathrm{E} b^{2}=$ a factor allowing for the influence of the moving weight;

$k_{d}=2 \mathrm{D} / \mathrm{E} b=\mathrm{a}$ factor allowing for the influence of the adjustable weight.

The measuring range of the instrument can be considerably extended by varying the adjustable weight, in which case it may no longer be possible to neglect the term $\mathrm{H}^{2}$. Consider $\mathrm{H}=\mathrm{H}_{0}+\mathrm{H}_{3}$, where $\mathrm{H}_{0}=k_{d} d$, in other words the level difference for $l=0$. When $\mathrm{H}^{2}$ is no longer negligible, $\mathrm{H}_{l}$ will be negligible in $\mathrm{H}^{2}$, whence: $\mathrm{H}_{l}=k_{g}\left(k_{a}+k_{\mathrm{H}}\right) l$, where $k_{\mathrm{H}}=\mathrm{H}^{2} / 2 b^{2}$, with the result that the calibration curves, which are spaced in steps of $\mathrm{H}_{0}$, will no longer run truly parallel. This small discrepancy can however be neglected in the majority of cases.

The addition of a small supplementary weight will be considered as occurring in the two following stages : 1) Placing the weight on the vertical running through the centre of gravity of the flotation aeras, which does not affect the equilibrium position of the apparatus, and 2) Horizontal displacement of the weight, which can be assimilated to an adjustable weight. In this way, the effect of the additional weight is easy to calculate beforehand.

The variations of the immersion $i$ for constant $d$ are given by :

$$
2 i=k_{g}\left(k_{a}-1\right) l \text {, becoming zero when } k_{a}=1
$$

No allowance has been made for the weight of the air, or, in more general terms, the ambient gas. However, its effect is not necessarily negligible, for the reading becomes dependent upon the specific gravity of the gas, or the ambient pressure and temperature. This undesirable effect is offset by balanc- ing the non-submerged volumes in such a way that their centre of gravity is in line with the weight resultant.

The easiest way to modify $k_{a}$ is by modifying $k_{h}$, and it can be made negative by changing the sign of $h$.

The sole requirement for a stable float is a positive stability modulus $d \mathrm{C} / d \alpha$. A righting couple $d \mathrm{C}$ tends to restore the apparatus to its equilibrium position whenever it diverges from it by $d \alpha$.

$$
\frac{d \mathrm{C}}{d \alpha}=k_{a} \frac{\mathrm{E} b^{2}}{2}
$$

In the limit, the magnification of the apparatus is infinite at zero stability, so that the stability condition does not prevent us from seeking a high magnification factor for the instrument. Lateral stability, can always be ensured if necessary by duplicating one of the floats, it does not affect the magnification.

If we assimilate the effects of surface tension and the amount of wetting to a tension $t$ per unit length of the water line acting in the opposite direction to the movement, we find that it amounts to a couple $2 \pi r t b$, H seing accurate to within $\pm \varepsilon$ :

$$
\varepsilon=\frac{4 t}{\bar{\omega} r}
$$

which can be reduced by increasing $r$.

The equilibrium equation provides us with a convenient means of calibrating the instrument. One merely lets it float on a single liquid surface, so that $\mathrm{H}=0$, and hence :

$$
k_{l}=-\frac{2 \mathrm{D}}{\mathrm{E} b} \frac{d}{l}
$$

D. $E$ and $b$ can all be measured to within the degree of accuracy required. The same graduation is used for measuring both $l$ and $d$; if there are no graduations on the level tube, a graduated stainless steel rule standing on edge above the tube can be used instead and will thus also serve to support the adjustable weight that is supported by the level if the latter is graduated.

It is difficult to apply the above calibration method to non-cylindrical floats. A more convenient method in this case is to use two containers, one floating inside the other, and varying the immersion by loading the floating container with known weights (Fig. 4). The floats of the instrument being calibrated are placed in these two containers. It is easy to see that the errors due to varying immersion and evaporation depend upon the difference between the inner and outer areas of flotation of the floating container, and they can in fact be rendered negligible.

Owing to the difference between the coefficients of expansion of the liquid and the level glass, the volume, length $B$ and the weight $A$ defined above all vary.

Since the overall weight of the apparatus remains constant, the variation $\Delta \mathrm{A}$ can be considered as the displacement of a weight $\Delta \mathrm{A}$ from the centre of 
the bubble to the centre of mass of the liquid in the level tube and we have the following:

$$
\mathrm{H}=k_{l} l+\frac{2 \Delta \mathrm{A}}{\mathrm{E} b}\left(l_{\mathrm{G}}-l\right)=k_{l} l+k_{b}\left(l_{\mathrm{G}}-1\right) \Delta B
$$

In calculating the above correction, $\Delta \mathrm{A}$ is assumed to be proportional to $\Delta \mathrm{B}$.

$k_{b}$ is easily determined from the reading $l$ and the length of the bubble $B$, for $H=0$, various ambient temperatures and values of $\mathrm{D} d$.

\section{Applications}

By facilitating the measurement of small pressure or level differences, this apparatus offers wide possibilities, particularly where the rates of flow of liquids or gases have to be measured. It enables this to be achieved practically without any increase in head loss and in no way interferes with the normal operation of the circuit to which it is applied. Typical uses made by the author are the measurement of the volume of air drawn in by an internal combustion engine and measuring the inflow of air into natural-draught furnace.

These micromanometers have also considerably widened the field of investigation for students concerned with flow measurement in pipes carrying air or water.

It has also been possible to use the instrument on a self-propelled carriage, where it was connected to a Pitot tube immersed in a stationary layer of water. In this instance, it gave satisfactory readings, which fully shows how little it matters whether the containers in which it is floating are rigidly mounted or not.

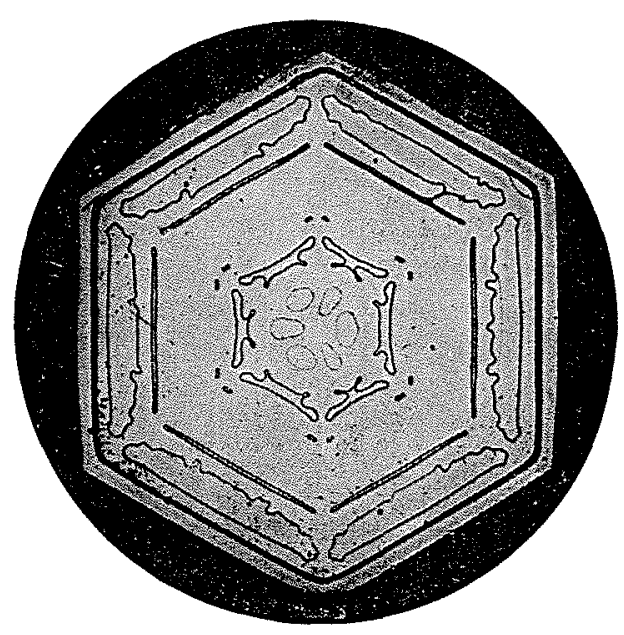

